\title{
A Study on the Regional Development Agencies as Project Based Development Model
}

\author{
Assoc. Prof. Dr. Sülün Evinç Torlak (Pamukkale University, Turkey) \\ Ph.D. Candidate Bilsev Gürsan (Pamukkale University, Turkey)
}

\begin{abstract}
Development concept, especially regional development concept has become the most important topic to even out the regional imbalances after the Second World War. The most important date has been after 1929, beginning with big crisis in the world. Regional development agencies which are the role of growth and development key have been established since the early of 1930's, initially in America, and then in European Countries together with in some other Eastern Countries. Today, the key role of the development within the framework of 'new development perception' form the basis of project logic, in other words; project based development model which the agencies are intervening notably. This model is on the agenda, with the strong impact of regional and cohesion politics of European Union and takes the role excessively through grants and funds which development agencies are seen as the place of implementation of those policies. Many different sector-specific projects from infrastructure to protection of heritage, presented to the related authorities are being executed. Supported projects within grants and funds help people changing viewpoints; improve competences and direct people to act through project logic as well. This case carries the meaning of the strong impact of development by relieving the problems or needs through projects. In this study, some definitions related with development, development project examples to the published extent by European Commission and the case of the model that is very new to Turkey within project examples of development agencies have been examined using the comparative analysis method.
\end{abstract}

JEL code: R11

\section{Introduction}

Today, regional development and regional policies have increased in importance more especially after the World crisis that took place in 1929. The policies providing the European Union Integration have identified the regionalism concept considerably. Regions, according to Maastricht agreement that strengthen the economic policies of European Union, are seen the guarantee of pluralism, rivalry, dispersion of work and effort, transparency, democracy, pertaining consciousness, solving of problems, integration, legality of political decisions, and efficiency. For an effective regional development policy the importance of "Regional institutionalization" moved out to foreground. This model has become the key development model which has first started in 1930's in America, then enlarged in Europe together with some eastern countries.

A Development Agency is an operational structure that identifies sect oral or overall development problems, chooses a range of opportunities or methodologies for their solution and promotes projects which can maximize the solutions to the problems. Helping in growing of economic, social and cultural areas are the common targets of agencies. The most important functions: To prepare regional development strategy and plan it for the regions. Funds that are saved in a common pool are handed out to the projects by regional development agencies. It is benefited from the project funds so that agencies lead to big regional changes. European countries support the funds, grants and ideas that will be effective for development. So they produce policies and projects. So from that direction, the development model predominantly exists as project based development. Small project cooperation turns into big projects and partnerships with those chances. Problems or needs are solved by producing projects in this direction.

Establishing period of development agencies in Turkey has started in 2006 within the frame of European Union cohesion policies. Agencies established at Level 2, is the beginning of project based development in Turkey. As the period is very new for Turkey, the supported projects by the agencies belong to 2007-2012 period.

\section{The Aim and the Methodology of the Research}

With this study, only a part of the study has been shared. In the basic study, the project examples of European Union have been analysed in order to announce the implementations of successful stories to suggest to those countries which have newly entered the process of project based development. Completed and going on projects of 27 European countries between the periods of 2000-2013 have been analysed under the title of European Commission-Regional Policies-Project Examples. Completed and going on projects of Turkey covers the period of 2007-2012. European Union Projects have been reached at "presented limit" by internet. Turkish projects have been reached through activity reports of agencies and the news on the press media. 
In this study, Project examples have been focused on 4 different categories through the numerical data using comparative analysis methods. Project analysis of development agencies have been scoped out through;

1- Sectoral Analysis

2- Partnership Analysis

3- Fund and Periodic Analysis

4- Country Analysis

\section{Sectoral Analysis of Development Agencies Projects}

\subsection{Sectoral Analysis in European Union Projects:}

There are 12 sectors that 27 European Union countries work on. These are: Business Support, Energy, Environment, Innovation, Research and Technological Development, Social Inclusion, Jobs, Education, Territorial Cooperation, Tourism and Culture, Transportation, Urban Development, Rural Development, Employment and Labour Market, Structural Funds.

Innovation, Research and Technological Development sector is the most worked on sector with 262 Project. The other sectors in turn are; Social Inclusion, Jobs, Education-199, Environment-172, Territorial Cooperation151, Entrepreneurship Support-141, Transportation-88, Urban Development-69, Energy-62,Culur and Tourism62, Rural Development-51, Employment-14, Structural Funds-2.

Employment and Labour Market and Structural Funds are the least worked on sector. Romania, producing 8 projects in Employment and Labour Market sector reflects the process of getting the European Union membership in 2007. The more Employment and Labour Market sector projects are the most expected result. Structural Fund holds the management and governance. Germany and Ireland are the only two countries working in this sector. These two sectors mean the process of assertive, difficult and long time needed effort. Figure 1, points out the sect oral dispersion.

\subsection{Sect oral Analysis of Turkey and Comparison:}

The number of worked on sectors in Europe is 12. The number of project sectors in Turkey is 66 until the period of 2012 .

The sectors are;

Small and Medium size Enterprise (SME) support, 2008 (223)

Economic Development

Direct Activity Support

These sectors are the most worked on sectors as Turkey part.

Although project based development starts newly in Turkey, the number of sectors is more than European project examples; over 5 times. The number of sectors is in great does not mean that lots of projects are being produced. While Innovation, Research and Technological Development sector is the most worked on sector in Europe, Turkey pays attention to economic development sector. While the founder members of Europe draw the successful country frame, Turkey draws it by the west part of it.

\section{Partnership Analysis of Development Agencies Projects}

\subsection{Partnership Analysis in European Union Projects}

Countries produce projects with a country or countries through building partnerships. Each country certainly goes to the partnership/s. France and Germany are the countries that build the most partnerships. These two countries have gone to partnership/s with the other 25/26 countries' projects. Countries except Spain, Sweden, Czech Republic, and Italy have built partnerships with one each. The reason why France and Germany are successful is related with the powerful capacity in partnership and communication. Besides, disciplined business concept and the high life standards also contribute for that. France distinguishes from the other countries in terms of partnerships. The most appealing part is; France goes to the partnership with each country and takes the role of each project sector. This side shows the high proof of the ability in building communication and cooperation. Building the most partnerships after France and German is the Netherlands. The last members of European Union are Bulgaria and Romania. Romania is more active than Bulgaria. Figure 2, points out the project partnership dispersion.

\subsection{Partnership Analysis of Turkey and Comparison}

Any partnerships have not been built abroad in Turkey. Project partnerships are at the very beginning period for Turkey while it is important for Europe as project content itself. Differences occur because Europe has started after 1950's and Turkey after 1990's. 


\section{Fund and Periodic Analysis of Development Agencies Projects}

\subsection{Fund and Periodic Analysis in European Union Projects}

The contribution of European Union is great; each project at a certain rate is supported. Funds can be divided in 2 categories; the real fund from the own resource of the project, the other is the contribution of the Union. European Regional Development Fund (ERDF) is the most funds that are benefited from. The other funds are below; Cohesion, Urban, Interreg, Objective, the countries 'own fund and Ispa funds. Each fund changes according to the country's conditions and the provided project categories. Except ERDF, the other funds have not got any usage frequency in order to put into; because those are not the intensive funds to put into an order like ERDF. Each country has those funds resources but the list does not go up 5 for each. Sampling covers the period of 2000-2013. Periods shows different time zones like 1, 2, and 3,4,5,6 years according to the fund resources: 2004-2009, 2004-2006, 2004-2008, 2006, 2007-2013.2007-2013 period is the most successful project period. Provided fund gives the project period of its own.

\subsection{Fund and Periodic Analysis of Turkey and Comparison}

The own budget of agencies have been used, any other contributions or supports have not been the case for Turkey's part. Except 2 agencies (Çukurova and Izmir) established in 2006, dynamism for the projects is seen in 2010-2012.

\begin{tabular}{|c|c|c|c|c|c|c|c|c|c|c|c|c|c|}
\hline & 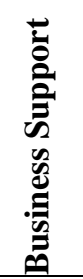 & 苞 & 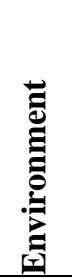 & 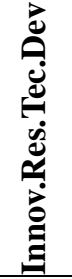 & 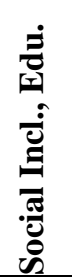 & 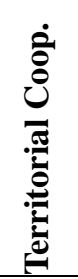 & 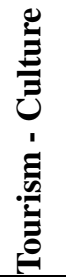 & 泀 & 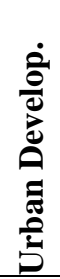 & 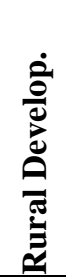 & 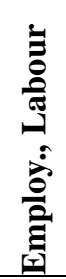 & 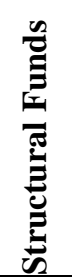 & 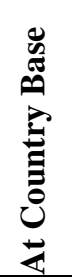 \\
\hline Austria & 6 & 3 & 7 & 14 & 7 & 3 & 2 & 1 & - & - & - & - & 43 \\
\hline Belgium & 13 & 1 & 3 & 12 & 13 & 3 & 4 & 2 & 4 & 1 & - & - & 56 \\
\hline Bulgaria & - & 1 & 4 & 2 & - & 2 & - & 5 & - & - & - & - & 14 \\
\hline Cyprus & 2 & - & - & - & 1 & - & 2 & 1 & 2 & 2 & 1 & - & 11 \\
\hline Czech Rep. & 2 & 1 & 1 & 5 & 10 & 3 & 2 & 4 & 2 & 2 & - & - & 32 \\
\hline Denmark & 6 & 3 & 3 & 3 & 3 & 6 & 1 & 1 & 1 & 1 & 1 & - & 29 \\
\hline Estonia & 3 & 2 & 5 & 3 & 1 & 5 & - & 2 & - & - & - & - & 21 \\
\hline Finland & 1 & 2 & 9 & 11 & 8 & 5 & 1 & 1 & 3 & 1 & - & - & 42 \\
\hline France & 5 & 4 & 16 & 27 & 15 & 8 & 7 & 7 & 7 & 2 & - & - & 98 \\
\hline Germany & 15 & 6 & 9 & 21 & 16 & 16 & 5 & 6 & 6 & 1 & 1 & 1 & 103 \\
\hline Greece & 3 & 1 & 5 & 5 & 6 & 5 & 2 & 4 & 1 & 2 & - & - & 34 \\
\hline Hungary & 7 & 3 & 7 & 7 & 12 & 4 & 3 & - & 3 & 3 & - & - & 49 \\
\hline Ireland & 7 & - & 4 & 4 & 8 & 9 & 3 & 4 & 3 & 3 & - & 1 & 46 \\
\hline Italy & 3 & 8 & 7 & 8 & 18 & 7 & 6 & 4 & 4 & 4 & - & - & 69 \\
\hline Latvia & 3 & 2 & 6 & 5 & 2 & 8 & 3 & 2 & 1 & 2 & - & - & 34 \\
\hline Lithuania & 3 & 3 & 6 & 8 & 2 & 10 & 2 & - & 2 & 2 & - & - & 38 \\
\hline Luxembourg & 2 & 2 & 2 & 2 & 2 & 1 & 1 & - & 1 & - & - & - & 13 \\
\hline Malta & - & 1 & 3 & 2 & 2 & - & 1 & - & 1 & 1 & - & - & 11 \\
\hline Netherlands & - & 1 & 4 & 16 & 5 & 5 & - & 3 & 7 & 6 & - & - & 47 \\
\hline Poland & 10 & 4 & 8 & 16 & 5 & 9 & 4 & 13 & 2 & - & 1 & - & 72 \\
\hline Portugal & 1 & 3 & 10 & 4 & 2 & 3 & 4 & 2 & 2 & 4 & - & - & 35 \\
\hline Romania & 11 & 1 & 5 & 7 & 4 & 5 & 1 & 3 & 1 & - & 8 & - & 46 \\
\hline Slovakia & 3 & - & 4 & 11 & 5 & 1 & 1 & 1 & - & - & - & - & 26 \\
\hline Slovenia & 2 & 1 & 3 & 4 & 3 & 1 & - & 2 & 1 & 1 & - & - & 18 \\
\hline Spain & 8 & 5 & 18 & 23 & 18 & 6 & 4 & 10 & 6 & 6 & - & - & 104 \\
\hline Sweden & 9 & 1 & 10 & 21 & 14 & 11 & 1 & 4 & 1 & 2 & 1 & - & 75 \\
\hline United King. & 16 & 3 & 13 & 21 & 17 & 15 & 2 & 6 & 8 & 5 & 1 & - & 107 \\
\hline At Sectoral Base & 141 & 62 & 172 & 262 & 199 & 151 & 62 & 88 & 69 & 51 & 14 & 2 & \\
\hline
\end{tabular}

Table 1: Sectoral Dispersion of EU Project Examples 


\begin{tabular}{|c|c|c|c|c|c|c|c|c|c|c|c|c|c|c|c|}
\hline & 引 & 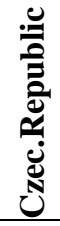 & 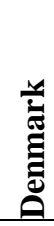 & 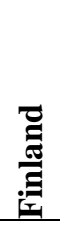 & 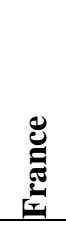 & 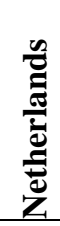 & 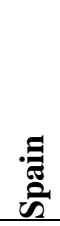 & 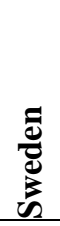 & $\stackrel{\vec{\sigma}}{\vec{\sigma}}$ & 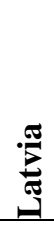 & 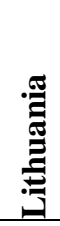 & $\underset{\Xi}{\overparen{E}}$ & 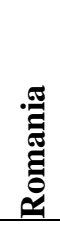 & 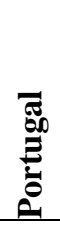 & U⿺辶ِّ \\
\hline Austria & & & & & $\mathrm{X}$ & $\mathrm{X}$ & & & $\mathrm{X}$ & & & & & & \\
\hline Belgium & $\mathrm{X}$ & $\mathrm{X}$ & & & $\mathrm{X}$ & & & & & & & & & & \\
\hline Bulgaria & $\mathrm{X}$ & & & & $\mathrm{X}$ & $\mathrm{X}$ & & & & & & & & & \\
\hline Cyprus & $\mathrm{X}$ & & & & $\mathrm{X}$ & & & & & & & & & & \\
\hline Czech Republic & $\mathrm{X}$ & & & & $\mathrm{X}$ & & & $\mathrm{X}$ & & & & & & & \\
\hline Denmark & $\mathrm{X}$ & & & & $\mathrm{X}$ & & & & & & & & & & \\
\hline Estonia & $\mathrm{X}$ & & & & $\mathrm{X}$ & & & $\mathrm{X}$ & & & & & & & \\
\hline Finland & $\mathrm{X}$ & & & & & $\mathrm{X}$ & & & $\mathrm{X}$ & & & & & & \\
\hline France & $\mathrm{X}$ & & & & $\mathrm{X}$ & & & & & & & & & & \\
\hline Germany & $\mathrm{X}$ & & & & $\mathrm{X}$ & & & & & & & & & & \\
\hline Greece & $\mathrm{X}$ & & & & $\mathrm{X}$ & & $\mathrm{X}$ & & & & & & & & \\
\hline Hungary & $\mathrm{X}$ & & & & $\mathrm{X}$ & & & & & & & & & $\mathrm{X}$ & \\
\hline Ireland & $\mathrm{X}$ & & $\mathrm{X}$ & $X$ & $\mathrm{X}$ & & & & & & & & & & \\
\hline Italy & $\mathrm{X}$ & & & & $\mathrm{X}$ & & & & & & & & & & \\
\hline Latvia & $\mathrm{X}$ & & & & $\mathrm{X}$ & & & & & & & & & & $\mathrm{X}$ \\
\hline Lithuania & $\mathrm{X}$ & & & & $\mathrm{X}$ & & & & & & $\mathrm{X}$ & & & & \\
\hline Luxembourg & $\mathrm{X}$ & & & & $\mathrm{X}$ & & & & & $\mathrm{X}$ & & & & & \\
\hline Malta & $\mathrm{X}$ & & & & $\mathrm{X}$ & $\mathrm{X}$ & & & & & & & & & \\
\hline Netherlands & $\mathrm{X}$ & & & & $\mathrm{X}$ & & & & & & & & & & \\
\hline Poland & $\mathrm{X}$ & & & & $\mathrm{X}$ & & & & & & & & & & \\
\hline Portugal & $\mathrm{X}$ & & & & $\mathrm{X}$ & & & & & & $\mathrm{X}$ & & & & \\
\hline Romania & $\mathrm{X}$ & & & & $\mathrm{X}$ & & $\mathrm{X}$ & & & & & & & & \\
\hline Slovakia & $\mathrm{X}$ & $\mathrm{X}$ & & & $\mathrm{X}$ & & & & & & & & & & \\
\hline Slovenia & $\mathrm{X}$ & & & & $\mathrm{X}$ & & & & & & & & & & \\
\hline Spain & $\mathrm{X}$ & & & & $\mathrm{X}$ & & & & & & & & & & \\
\hline Sweden & $\mathrm{X}$ & & & & $\mathrm{X}$ & & & & & & & & $\mathrm{X}$ & & \\
\hline United Kingdom & $X$ & & & & $\mathrm{X}$ & & & & & & & $X$ & & & \\
\hline Total & 27 & 2 & 1 & 1 & 27 & 4 & 2 & 2 & 2 & 1 & 2 & 1 & 1 & 1 & 1 \\
\hline
\end{tabular}

Table 2: Partnership Dispersion of EU Project Examples

\section{Country Analysis of Development Agencies Projects}

\subsection{Country Analysis in European Union Project}

The most hardworking countries: United Kingdom (UK) with 107 projects, Spain-104, Germany-103

The least hardworking countries: Malta, Northern Cyprus, and Luxembourg

Sectoral Analysis of the most and the least hardworking countries;

United Kingdom-Spain; UK in two sectors; Entrepreneurship, Employment and Labour Market with Territorial Cooperation, has produced the most projects compared with Spain. UK is twice as much of Spain in the rate of Business Support.

Germany-United Kingdom; they are very close in terms of sect oral point .Germany in one sector ahead of UK. Two countries are successful in two different sectors. Germany has worked on Tourism and Energy projects. UK has produced in Environment and Rural Development sectors.

Spain-Germany; they are very close in terms of project numbers. While Spain is giving importance to Environment, Social Inclusion, Transportation, Germany pays attention to every project sectors with a special effort for structural funds; she has managed to benefit from the Structural Funds.

\subsection{Country Analysis of Turkey and Comparison:}

As the process is new for Turkey, there is not any country cooperation among the agencies. 


\section{Conclusion}

Project analysis's show that European Union is achieving the project based development well for the long years. When projects and project partnerships examined, it can easily be noticed that at least eight countries are coming together in order to solve the related problem through the project activities. This situation from the rotation of project based development is also the clear indicator of regional development, governance, participation and sustainability. Agencies that have been established in different status and support carry the meaning of sharing the different experiences; Like Finland and Austria. They are going into continental cooperation. It is also good example. Some countries can easily be observed that they have been executing more project based works. Besides, it is seen that these countries are the countries that have taken the role of founder members of Union and provided contributions more at the first stage. It is seen that the countries which joined the Union late have been producing the least projects.

That the projects examples have been examined at the presented limit, give the clues about the structural parts of the whole. In this context, the structure of European Union development projects is picked up at the triangle of Innovation, Research and Technological Development sector. Innovation, Research and Technological Development sector is expected result for Europe when the other parts of development sectors are always in a certain growth. That the European Union gives the special value for innovation and to meet with this value through European programs and projects is not coincidence.

That the Project based development is being implemented through the funds and grants effectively is also stated in European Strategy 2020 paper. Understanding the project importance is at the beginning level in Turkey. It is suggested Turkey should have examine the European projects as it will be more effective. Project based development in the countries like USA, Japan, South Korea and Taiwan play important role at this point.

\section{References}

- Apan, 2005. "Regional Concept and Regional Development Agencies", Modern Local Administrations Magazine, 13/4, p.39-58

- Arslan, 2010. "Development Agencies and Expected Contributions of Development Agencies To Turkish Economy", Master Thesis, p.11-19

- $\quad$ Eurada, 1999. Creation, development and management of rdas, http://www.largis.org.ua/largis2/english/doc/REA_creation_EURADA.pdf

- $\quad$ European Commission, 2011.Regional policy, inforegio, http://ec.europa.eu/regional_policy/projects/stories/search.cfm?LAN=EN\&pay=CZ\&region= ALL\&the $=$ ALL\&type $=$ STO\&per $=2$.

- Gündüz, 2006. Regional Development Policies, Ekin Publications, Bursa

- Kayasü and Yaşar, 2006. "Development Policies in the process of European Union Membership": Legal and Institutional Transformation” Symposium on Regional Development And Governance, p.203.

- Planning Organization of State, “Turkey Eight Development Plan”, 2001-2005, p. 4, 5

- S S Sen, 2008. "Regional Development and Grant Programmes", From Planning to Implementation, 3.Regional Development and Governance, p.376.

- Torlak and Gürsan, 2012. “A study on Agencies of European Union”, Socio-Cultural Differences and Alloyed Locations-City and Cities, 1, p.191. 